\title{
New Effective Sorbents for Removal of Am-241 from Drinking Water
}

\author{
Agnieszka Gladysz-Płaska ${ }^{1,3 *}$, Agata Oszczak², Leon Fuks², Marek Majdan \\ ${ }^{1}$ Faculty of Chemistry, Maria Curie-Skłodowska University, M. C. Sklodowska Sq. 2, 20-031 Lublin, Poland \\ ${ }^{2}$ Institute of Nuclear Chemistry and Technology, Dorodna 16, 03-195 Warszawa, Poland \\ ${ }^{3}$ On leave in the Institute of Nuclear Chemistry and Technology, Dorodna 16, 03-195 Warszawa, Poland
}

Received: 18 January 2016

Accepted: 12 April 2016

\begin{abstract}
Two new sorbents for americium(III) removal from an aqueous environment were studied: Volclay bentonite and red clay - both modified by a cationic surfactant (hexadecyltrimethylammonium bromide) and phosphate ions. Sorption of Am(III) was investigated using the batch method. It was concluded that the kinetics of Am(III) sorption on both sorbents can be evaluated based on the pseudo-second-order rate equation. The following two-parameter equations - Langmuir-Freundlich, Temkin, and DubininRadushkevich isotherms - were examined for their ability to model equilibrium sorption data. It was shown that bentonite and red clay modified by phosphate ions exhibited better sorption properties toward Am(III) ions than sodium forms of the adsorbents. This was probably a result of the complexation of Am(III) ions by $\mathrm{PO}_{4}^{3-}$ ions immobilized on the adsorbent surface in the form of ionic pairs with surfactant cations. Changes in $\mathrm{Am}$ (III) sorption with $\mathrm{pH}$ were modeled based on the molar fractions of the particular complexes in the aqueous phase, and it was concluded that $\mathrm{Am}\left(\mathrm{CO}_{3}\right)_{3}{ }^{3-}$ and $\mathrm{Am}(\mathrm{OH})_{3}$ species had a predominant influence on the overall sorption process.
\end{abstract}

Keywords: water treatment, Volclay bentonite, red clay, americium-241, sorption, irradiation

\section{Introduction}

Storage of radioactive waste requires the use of various protective barriers against the leaching of radionuclides present in the waste, such as metal canisters (tanks), buffers made of metal ion adsorbents, and often the surrounding rocks. Such barriers should also prevent ambient humidity from penetrating into the storage tanks. Various biopolymers and naturally occurring inorganic adsorbents have already been examined as inexpensive

*e-mail: agnieszka.gladysz.plaska@onet.pl and abundant materials able to considerably slow down radionuclide migration rates [1].

Volclay MX80 bentonite, an aluminum silicate clay formed from volcanic ash, has for the last 20 years been intensively studied in different laboratories as a compact barrier for nuclear waste repositories [2-12], and has been found suitable for this purpose. Bentonite, which is a readily available mineral in Poland, has been tested as a potential buffer at the National Radioactive Waste Repository in Rozan, Poland, as part of the strategic project Technologies Supporting Development of Safe Nuclear Power Engineering, Domain 4 "Development of spent nuclear fuel and radioactive waste management techniques and technologies." It has also been tested at 
the Institute of Nuclear Chemistry and Technology as a sorbent for removal of radionuclides that could potentially contaminate water.

The aim of the present work was to compare bentonite and natural red clay as adsorbents of trivalent ions of americium-241. This radionuclide is the only actinide element used in households, in smoke detectors [13]. These sensors use ${ }^{241} \mathrm{Am}$ in the form of a dioxide as a source of radiation that ionizes air [14-15]. Alpha radiation emitted by this radionuclide, in combination with beryllium, forms an efficient neutron source (owing to the large cross-section of beryllium-9) for the $(\alpha, n)$ nuclear reaction. Am241 is also used as a portable source of both gamma rays and alpha particles applied in medicine and industry. The $\sim 60-\mathrm{keV}$ gamma ray emissions from Am-241 in these sources can be used for indirect analysis of materials in radiography and x-ray fluorescence spectroscopy, as well as for quality control and nuclear dosimeters. Because of that, Am-241 is a significant component of radioactive waste and an important test of barrier efficiency for Am241-containing repositories.

Another goal of the present study was to investigate the sorption of trivalent Am-241 cations on different forms of Volclay bentonite and red clay: sodium forms (both normal and gamma-irradiated specimens) and phosphatemodified forms. The choice of sodium and phosphates as surfactants was based on recent studies that showed that organoclays exhibited an increased affinity for anions as a result of the change in surface mineral charge from negative to positive after modification with surfactant cations [18-19]

In view of the possibility of using the two adsorbents for removing trivalent Am-241 ions from radioactive waste, it was justified to examine the properties of the sorbents after gamma radiation. Additionally, since there are reports on the higher sorption of uranyl ions in the presence of phosphate ions [16-17], we found it interesting to investigate the effects of phosphate ions on the sorption of trivalent Am-241 ions.

The adsorbents bentonite clay and red clay modified with phosphate ions were tested for the first time for their ability to remove Am (III) ions from an aqueous medium. The literature to date offers no studies on americium sorption in similar systems.

\section{Material and Methods}

\section{Materials}

Drinking water was collected in the Institute of Nuclear Chemistry and Technology (Warsaw). Post-decontamination liquids were simulated by dissolving $21 \mathrm{~g}$ of citric acid monohydrate in $100 \mathrm{~cm}^{3}$ of the collected water to obtain a $0.1 \mathrm{M}$ solution. We use nitric acid (fuming; ChemPur, Piekary Śląskie, Poland), sodium hydroxide (pure p.a.; Avantor Performance Materials, Gliwice, Poland), sodium nitrate ( $\geq 99.0 \%$; Sigma Aldrich), and citric acid monohydrate (pure; Avantor).
Aqueous solutions of the desired Am-241 concentration were prepared by weight dilution of a certified standard solution delivered by the National Centre for Nuclear Research (Radioisotope Centre POLATOM, Świerk, Poland), with the drinking water or the citrate solution, respectively, prior to analysis by gamma spectrometry.

A granular form of Volclay bentonite (P.W. Structum Ltd, Lublin, Poland) was converted to a sodium form, which was designated Na-bentonite by equilibration of $5 \mathrm{~g}$ of raw bentonite with $100 \mathrm{~cm}^{3}$ of a $1 \mathrm{M}$ aqueous solution of $\mathrm{NaCl}$ (pure p.a.; Avantor Performance Materials). A sodium form of red clay, designated as Na-clay, was prepared by equilibrating a raw clay product (R-clay) delivered by Geolmin with $100 \mathrm{~cm}^{3}$ of a $1 \mathrm{~mol} / \mathrm{dm}^{3}$ solution of $\mathrm{NaCl}$ (pure p.a.; Avantor Performance Materials). The chemical compositions of Volclay bentonite and red clay are presented in Results and Discussion.

The $\mathrm{PO}_{4}$-bentonite and $\mathrm{PO}_{4}$-red clay used in the sorption experiments were prepared as follows: a 1-g sample of a $\mathrm{Na}$ adsorbent (bentonite or red clay) was equilibrated for $4 \mathrm{~h}$ using a mechanical shaker with $100 \mathrm{~cm}^{3}$ of a $1 \mathrm{mM}$ hexadecyltrimethylammonium bromide solution (HDTMA, Sigma-Aldrich, $99 \%$ purity) at $333 \mathrm{~K}\left(60^{\circ} \mathrm{C}\right)$. The solid residue from filtration was rinsed twice with distilled water, then dried in the air, powdered in an agate mortar, and passed through a $0.1 \mathrm{~mm}$ sieve. The product obtained was called an HDTMA adsorbent (bentonite or red clay). As the next step, $1 \mathrm{~g}$ of the HDTMA adsorbent was equilibrated for $4 \mathrm{~h}$ using a mechanical shaker with $100 \mathrm{~cm}^{3}$ of $0.1 \mathrm{M} \mathrm{Na}_{3} \mathrm{PO}_{4}$ (pure p.a.; Avantor Performance Materials, Poland), dried in the air, powdered, and passed through a $0.1 \mathrm{~mm}$ sieve. The final product was called a $\mathrm{PO}_{4}$-adsorbent.

\section{Adsorption Experiments}

Adsorption experiments on Na-bentonite, $\mathrm{PO}_{4}$-bentonite, Na-red clay, and $\mathrm{PO}_{4}$-red clay were performed to obtain the values of optimum $\mathrm{pH}$, contact time, and initial concentration of Am(III) ions. For each experiment, about $0.01 \mathrm{~g}$ of a sorbent was added to $30 \mathrm{~cm}^{3}$ of an americium(III) aqueous solution (Falcon Conical Tubes) and shaken for $6 \mathrm{~h}$ at room temperature (Heildolph Multi Reax). After separation of the phases, the concentration of Am(III) in the equilibrium solutions was determined radiometrically in a well-type counter (Perkin Elmer 2480 Wizard Automatic Gamma Counter). To assure a constant geometry of the measurements, all liquid samples were diluted with water to a volume of $2 \mathrm{~cm}^{3}$. The measuring set was calibrated for Am-241 $\left(\mathrm{E}_{\gamma}=59.5 \mathrm{keV}\right)$ as $880 \mathrm{cpm} \cdot \mathrm{cm}^{-3}$, corresponding to $0.19 \mathrm{MBq} \cdot \mathrm{cm}^{-3}$ of radiation emitted by the radionuclide. The initial concentration of americium was $2.07 \cdot 10^{-8} \mathrm{~mol} / \mathrm{dm}^{3}$ for all the experiments, except for those carried out to determine the effect of the initial concentration of americium.

The $\mathrm{pH}$ of the solutions was adjusted in the range of 2-10 using $\mathrm{NaOH}$ or $\mathrm{HNO}_{3}$ aqueous solutions. Several contact times $(15,30,45,60,120,180,240,300$, and $360 \mathrm{~min})$ were applied to obtain the steady-state time 
of the adsorption process. Various aqueous solutions of americium ions with concentrations varying from $0.19 \mathrm{MBq} \cdot \mathrm{cm}^{-3}$ to $1.9 \mathrm{MBq} \cdot \mathrm{cm}^{-3}$ were prepared to study the isotherm models at $296 \mathrm{~K}\left(23^{\circ} \mathrm{C}\right)$.

Adsorption properties of Volclay bentonite and red clay were calculated using the following equations:

- Distribution coefficient $\mathrm{K}_{\mathrm{d}}\left(\mathrm{dm}^{3} / \mathrm{g}\right)$ :

$$
K_{d}=\left(\frac{\left(c_{0}-c_{e q}\right.}{c_{e q}}\right) \times \frac{V}{m}=\frac{\left(a_{0}-a\right)}{a} \times \frac{V}{m}
$$

- $\quad$ Sorption percentage R (\%):

$$
R=\frac{100 \% \times K_{d}}{\left(K_{d}+\frac{V}{m}\right)}
$$

- Equilibrium concentration $\mathrm{c}_{\mathrm{eq}}\left(\mathrm{mol} / \mathrm{dm}^{3}\right)$ :

$$
c_{e q}=\frac{c_{0} \times a}{a_{0}}
$$

The concentrations of Am(III) ions in the clay phase $\left(c_{s}\right)$ in $\mathrm{mol} / \mathrm{g}$ were calculated from the relationship:

$$
c_{s}=\left(c_{0}-c_{e q}\right) \times \frac{V}{m}
$$

...where $c_{s}, c_{0}$, and $c_{e q}$ denote the concentrations of Am(III) ions in the clay phase, the initial solution, and the equilibrium solution, respectively. The letter symbols $\mathrm{a}_{\mathrm{s}}, \mathrm{a}_{0}$, and $\mathrm{a}_{\mathrm{eq}}$, in turn, stand for the appropriate activity of the radiation measured $\left(\mathrm{Bq} \mathrm{cm}^{-3}\right)$. The symbols $\mathrm{V}$ and $\mathrm{m}$ relate to the volume of solution in $\mathrm{cm}^{3}$ and mass in $\mathrm{g}$, respectively. In each experiment, the mean sorption percentage was estimated from triplicate measurements.

\section{X-ray Diffraction Analysis}

X-ray powder diffraction measurements of the clay samples were made using a conventional DRON-3 diffractometer (Russia). The measurement conditions were as follows: radiation, $\mathrm{Cu} \mathrm{K \alpha}$; wave-length discrimination, Ni filter, pulse height analyzer; detector, scintillation; divergence slit, 0.3 ; receiving slit, $0.15^{\circ}$; range, $2010-90^{\circ}$; step size, $0.02^{\circ}$; count time per step, $20 \mathrm{~s}$; calibration standards, SRM640/NISt. Analysis of the x-ray diffraction

\begin{tabular}{|c|c|c|c|c|c|}
\hline \multirow{3}{*}{ Element } & & \multicolumn{4}{|c|}{ Concentration } \\
\hline & & \multicolumn{2}{|c|}{ Bentonite } & \multicolumn{2}{|c|}{ Red clay } \\
\hline & & Non-irradiated & Irradiated & Non-irradiated & Irradiated \\
\hline Al & $\%$ & $11 . \pm 1.7$ & $10.9 \pm 1.5$ & $9.3 \pm 1.2$ & $11.8 \pm 1.5$ \\
\hline $\mathrm{Mg}$ & $\%$ & $1.4 \pm 0.2$ & $1.5 \pm 0.2$ & $1.4 \pm 0.1$ & $1.5 \pm 0.2$ \\
\hline $\mathrm{Na}$ & $\%$ & $1.2 \pm 0.2$ & $2.5 \pm 0.4$ & $0.5 \pm 0.02$ & $0.8 \pm 0.03$ \\
\hline $\mathrm{Si}$ & $\%$ & $29.8 \pm 4.5$ & $26.3 \pm 3.5$ & $30.3 \pm 5.1$ & $32.3 \pm 4.9$ \\
\hline $\mathrm{Fe}$ & $\%$ & $4.4 \pm 0.7$ & $4.4 \pm 0.7$ & $5.1 \pm 1.3$ & $5.5 \pm 1.1$ \\
\hline $\mathrm{K}$ & $\%$ & $1.3 \pm 0.3$ & $0.9 \pm 0.1$ & $2.2 \pm 0.2$ & $1.8 \pm 0.2$ \\
\hline $\mathrm{Ca}$ & $\%$ & $0.38 \pm 0.1$ & $0.35 \pm 0.13$ & $0.28 \pm 0.05$ & $0.3 \pm 0.1$ \\
\hline Mn & ppm & $1353.5 \pm 203.0$ & $1545.5 \pm 231.8$ & $700 \pm 176$ & $879 \pm 134$ \\
\hline $\mathrm{Sr}$ & ppm & $437.0 \pm 65.6$ & $588.5 \pm 88.3$ & - & - \\
\hline $\mathrm{Ba}$ & ppm & $524.0 \pm 42.4$ & $674.0 \pm 101.1$ & - & - \\
\hline $\mathrm{V}$ & ppm & $96.5 \pm 14.5$ & $113.5 \pm 17.0$ & - & - \\
\hline $\mathrm{Zn}$ & ppm & $99.1 \pm 14.9$ & $127.0 \pm 19.1$ & $76.2 \pm 12.2$ & $62.2 \pm 5.5$ \\
\hline $\mathrm{Pb}$ & ppm & $32.7 \pm 4.9$ & $33.8 \pm 5.1$ & - & - \\
\hline $\mathrm{Cu}$ & ppm & $50.0 \pm 7.5$ & $30.7 \pm 4.6$ & $33.4 \pm 4.5$ & $21.4 \pm 3.3$ \\
\hline $\mathrm{Rb}$ & ppm & $55.0 \pm 8.3$ & $64.5 \pm 9.7$ & - & - \\
\hline $\mathrm{Ce}$ & ppm & $84.5 \pm 12.7$ & $89.0 \pm 13.4$ & - & - \\
\hline
\end{tabular}
patterns was performed using a whole-powder-pattern-fitting computer program.

Table 1. Chemical composition of the Volclay bentonite used in the studies (ED XRF), major components. 
a)

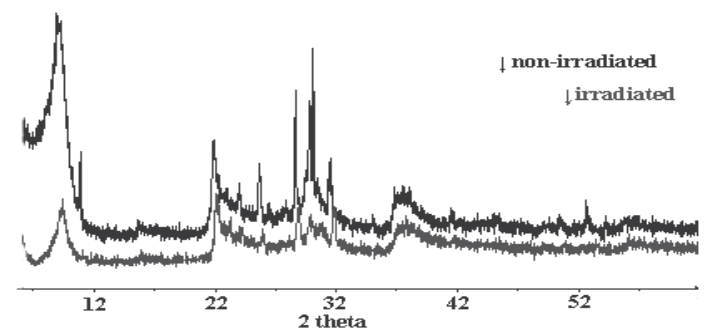

b)

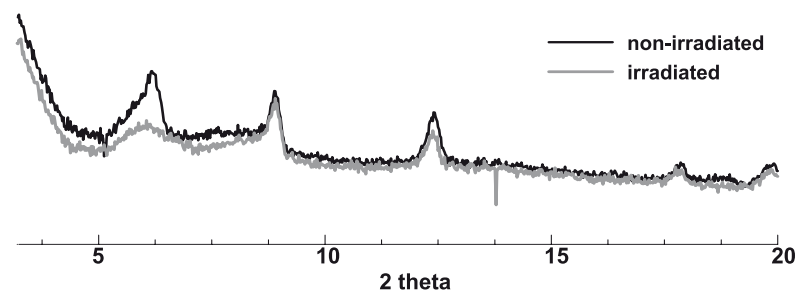

Fig. 1. Powder x-ray diffraction plots of Na-bentonite a) and Nared clay $b$ ); the upper plot corresponds to the natural material, the lower to the gamma-irradiated one.

\section{Results and Discussion}

To check whether the sorbents could be used as engineering barriers, the radiation stability of granular Volclay bentonite and raw red clay was studied by gamma-irradiation in a cobalt bomb at the Institute of Nuclear Chemistry and Technology. A dose of 100 kGy was applied. Certain properties of the irradiated sorbents, among them sorption, were compared with those of the non-irradiated material.

The chemical compositions of Na-bentonite and Nared clay are presented in Table 1 . The similarity in the composition of the irradiated and the non-irradiated material suggests that no decomposition occurred upon gamma radiation.

Powder x-ray diffraction studies revealed that Na-bentonite - both natural and irradiated - had a layered structure (see Fig. 1a). However, a shift of the small $2 \theta$ angle peak from $7.037 \mathrm{deg}$ to $7.350 \mathrm{deg}$ suggested that upon irradiation the distance between the layers decreased from $12.551 \AA$ to $12.069 \AA$.

There was no observable change in the structure of the red clay after irradiation, but an evident decrease in the intensity of the $6.2^{\circ}$ peak, responsible for the interlamellar space of illite, was visible after irradiation (Fig. 1b).

\section{Adsorption Study}

We investigated the sorption of Am(III) on bentonite and red clay as a function of contact time from 15 to $360 \mathrm{~min}$ using an initial concentration of $2.07 \cdot 10^{-8} \mathrm{~mol} / \mathrm{dm}^{3}$ of Am-241 in aqueous solutions. The results of these experiments are reported in Fig. 2. As can be seen from this figure, the adsorption of Am(III) rapidly increased with the increasing contact time of up to $180 \mathrm{~min}$. Shaking for a longer time did not significantly

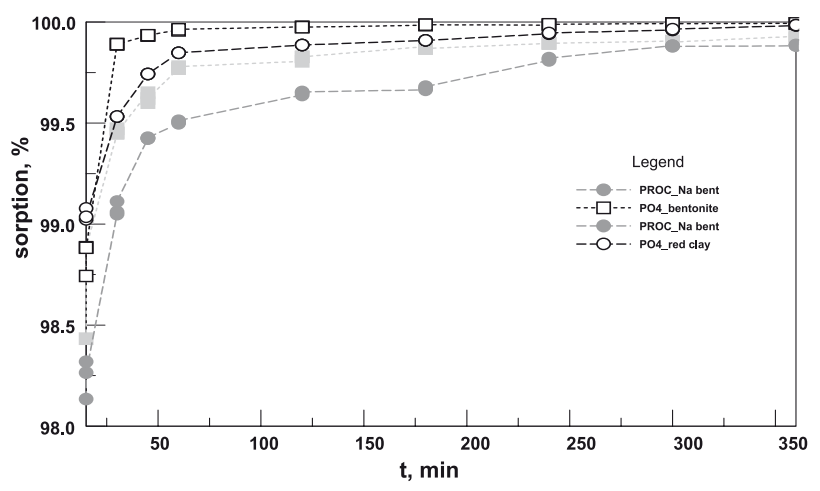

Fig. 2. Effect of time on Am-241 sorption on Volclay-bentonite (Na-bentonite and $\mathrm{PO}_{4}$-bentonite) and red clay $\left(\mathrm{Na}\right.$ and $\mathrm{PO}_{4}$ red clay), $\mathrm{c}_{\text {in }}=2.07 \times 10^{-8} \mathrm{~mol} / \mathrm{dm}^{3}$.

affect the percentage of Am(III) sorption. Sorption equilibrium was reached after about $4 \mathrm{~h}$ of shaking, and the efficiency was about $99.8 \%$ for the Na-sorbent forms and $99.9 \%$ for the $\mathrm{PO}_{4}$-sorbent forms. Initial uptake can be attributed to the concentration gradient of Am(III) and to the greater number of available binding sites. In the second stage of Am(III) uptake, active bonding sites of the sorbent had already been largely occupied by Am(III), which reduced the number of active sites ready to adsorb Am(III) [21-23].

The experimental data on Am-241 adsorption on Volclay bentonite and red clay were analyzed by two kinetic reaction models: Lagergren's pseudo-first-order model and Ho's pseudo-second-order model. The linear form of the pseudo-first-order kinetic equation as given by Lagergren is:

$$
\log \left(q_{e}-q_{t}\right)=\log q_{e}-\left(k_{1} / 2.303\right) \cdot t
$$

... where $\mathrm{q}_{\mathrm{e}}$ and $\mathrm{q}_{\mathrm{t}}$ are the amount of Am ions adsorbed at equilibrium in $\mathrm{mol} / \mathrm{g}$ and at time $\mathrm{t}$ in $\mathrm{min}$, respectively, and $\mathrm{k}_{1}$ is the pseudo-first-order rate constant $(1 / \mathrm{min})$. Lagergren's first-order rate constant $\left(\mathrm{k}_{1}\right)$ and $\mathrm{q}_{\mathrm{e}}$ determined from the model are shown in Table 2 along with the corresponding correlation coefficients.

Pseudo-second-order kinetics can be expressed as:

$$
t / q_{t}=1 / k_{2} q_{e}^{2}+\left(1 / q_{e}\right) \cdot t
$$

...where $\mathrm{k}_{2}(\mathrm{~g} / \mathrm{mg} \cdot \mathrm{min})$ is the second-order adsorption rate constant, $\mathrm{q}_{\mathrm{e}}(\mathrm{mol} / \mathrm{g})$ stands for the amount of Am ions adsorbed at equilibrium, and $\mathrm{q}_{\mathrm{t}}(\mathrm{mol} / \mathrm{g})$ is the amount of Am ions adsorbed at the desired time $t$ [24-25]. The equilibrium adsorption capacity $\left(\mathrm{q}_{\mathrm{e}}\right)$ and the second-order constants $\mathrm{k}_{2}$ determined from the model are shown in Table 2 along with the corresponding correlation coefficients. As can be seen, the pseudo-second-order model represents adsorption kinetics most accurately, and the calculated $\mathrm{q}_{\mathrm{e}}$ values are compatible with the experimental $\mathrm{q}_{\mathrm{e}}$ values (Table 2). This suggests that the adsorption of Am ions on all studied forms of bentonite and red clay follows pseudo-second-order kinetics. According to Ho and McKay 
Table 2. Parameters of the kinetic and isotherm models for the adsorption of the Am-241 on bentonite and red clay, ( $\mathrm{R}^{2}-$ correlation).

\begin{tabular}{|c|c|c|c|c|c|c|c|}
\hline Model & Parameter & Na-bentonite & $\begin{array}{l}\text { Irradiated } \\
\text { bentonite }\end{array}$ & $\mathrm{PO}_{4}$-bentonite & Na-red clay & Irradiated red clay & $\mathrm{PO}_{4}$-red clay \\
\hline \multirow{3}{*}{$\begin{array}{l}\text { Pseudo-first } \\
\text { - order }\end{array}$} & $\begin{array}{c}\mathrm{k}_{1} \\
(1 / \mathrm{min})\end{array}$ & $1.6 \cdot 10^{-3}$ & $1.8 \cdot 10^{-3}$ & $2.35 \cdot 10^{-3}$ & $1.6 \cdot 10^{-3}$ & $1.8 \cdot 10^{-3}$ & $2.35 \cdot 10^{-3}$ \\
\hline & $\begin{array}{c}\mathrm{q}_{\mathrm{e}} \text { calc } \\
(\mathrm{mol} / \mathrm{g})\end{array}$ & $1.39 \cdot 10^{-9}$ & $1.42 \cdot 10^{-9}$ & $1.62 \cdot 10^{-9}$ & $1.38 \cdot 10^{-9}$ & $1.42 \cdot 10^{-9}$ & $1.62 \cdot 10^{-9}$ \\
\hline & $\mathrm{R}^{2}$ & 0.7564 & 0.7745 & 0.7560 & 0.6754 & 0.4789 & 0.5222 \\
\hline \multirow{3}{*}{$\begin{array}{l}\text { Pseudo-se- } \\
\text { cond-order }\end{array}$} & $\begin{array}{c}\mathrm{k}_{2} \\
(\mathrm{~g} / \mathrm{mol} \min )\end{array}$ & 35714 & 35714 & 30303 & 3546 & 3498 & 3058 \\
\hline & $\begin{array}{c}\mathrm{q}_{\mathrm{e}} \text { calc } \\
(\mathrm{mol} / \mathrm{g})\end{array}$ & $3 \cdot 10^{-6}$ & $3 \cdot 10^{-6}$ & $6 \cdot 10^{-6}$ & $2.8 \cdot 10^{-6}$ & $2.8 \cdot 10^{-6}$ & $5.99 \cdot 10^{-6}$ \\
\hline & $\mathrm{R}^{2}$ & 0.9997 & 0.9997 & 0.9997 & 0.9997 & 0.9997 & 0.9993 \\
\hline \multirow{4}{*}{$\begin{array}{l}\text { Langmuir- } \\
\text { Freundlich }\end{array}$} & $\begin{array}{c}\mathrm{K}_{\mathrm{L-F}} \\
\left(\mathrm{dm}^{3} / \mathrm{mol}\right)\end{array}$ & 6461.1 & 6510.8 & 22717.4 & 1837.7 & 2176.2 & 23237.3 \\
\hline & $\mathrm{n}$ & 0.81 & 0.88 & 0.91 & 0.87 & 0.61 & 0.68 \\
\hline & $\underset{(\mathrm{mol} / \mathrm{g})}{\mathrm{q}_{\max }}$ & $3.4 \cdot 10^{-6}$ & $3.04 \cdot 10^{-6}$ & $3.74 \cdot 10^{-5}$ & $2.64 \cdot 10^{-6}$ & $2.69 \cdot 10^{-6}$ & $2.76 \cdot 10^{-5}$ \\
\hline & $\mathrm{R}^{2}$ & 0.9645 & 0.9945 & 0.9951 & 0.9658 & 0.9915 & 0.9943 \\
\hline \multirow{4}{*}{$\begin{array}{c}\text { Dubinin-Ra- } \\
\text { dushkevich }\end{array}$} & $\begin{array}{c}\mathrm{K}_{\mathrm{D}-\mathrm{R}} \\
\left(\mathrm{mol}^{2} / \mathrm{kJ} \mathrm{J}^{2}\right)\end{array}$ & $3.51 \cdot 10^{-9}$ & $4.44 \cdot 10^{-9}$ & $5.43 \cdot 10^{-9}$ & $3.3 \cdot 10^{-9}$ & $3.2 \cdot 10^{-9}$ & $4.35 \cdot 10^{-9}$ \\
\hline & $\begin{array}{c}\mathrm{Q}_{\mathrm{m}} \\
(\mathrm{mol} / \mathrm{g})\end{array}$ & $2.47 \cdot 10^{-6}$ & $2.19 \cdot 10^{-6}$ & $2.18 \cdot 10^{-5}$ & $2.3 \cdot 10^{-6}$ & $2.22 \cdot 10^{-6}$ & $9.38 \cdot 10^{-6}$ \\
\hline & $\begin{array}{c}\text { En } \\
(\mathrm{kJ} / \mathrm{mol})\end{array}$ & 11.93 & 10.61 & 9.59 & 11.38 & 11.56 & 10.72 \\
\hline & $\mathrm{R}^{2}$ & 0.9483 & 0.9963 & 0.9929 & 0.9674 & 0.9796 & 0.9882 \\
\hline \multirow{3}{*}{ Temkin } & $\begin{array}{c}\mathrm{b}_{\mathrm{T}} \\
(\mathrm{J} / \mathrm{mol})\end{array}$ & 10107.88 & 9575.5 & 4350.7 & 12315.5 & 15525.8 & 4471 \\
\hline & $\begin{array}{c}\mathrm{K}_{\mathrm{T}} \\
\left(\mathrm{dm}^{3} / \mathrm{g}\right)\end{array}$ & 156.03 & 169.02 & 290.1 & 130.33 & 192.49 & 340.4 \\
\hline & $\mathrm{R}^{2}$ & 0.9453 & 0.9598 & 0.9598 & 0.9552 & 0.9528 & 0.9851 \\
\hline \multirow{3}{*}{ Langmuir } & $\begin{array}{c}\mathrm{K}_{\mathrm{L}} \\
\left(\mathrm{dm}^{3} / \mathrm{mol}\right)\end{array}$ & 1134.01 & 2408.05 & 4975.90 & 1347.78 & 139.68 & 2013.88 \\
\hline & $\underset{(\mathrm{mol} / \mathrm{g})}{\mathrm{q}_{\max }}$ & $8.05 \cdot 10^{-5}$ & $4.7 \cdot 10^{-5}$ & $9.97 \cdot 10^{-5}$ & $2.7 \cdot 10^{-4}$ & $1.9 \cdot 10^{-4}$ & $3.8 \cdot 10^{-4}$ \\
\hline & $\mathrm{R}^{2}$ & 0.9438 & 0.9641 & 0.9637 & 0.9555 & 0.9622 & 0.9668 \\
\hline
\end{tabular}

[26-27], if an adsorption process follows the pseudo-second-order model, the mechanism of adsorption is mainly chemical bonding or chemisorption.

Studies on the equilibrium isotherms provide information about the sorption mechanism, surface properties, and binding sites of the sorbent [28-30]. The Langmuir, Langmuir-Freundlich, Temkin, and Dubinin-Radushkevich model of isotherms were selected for examination for their ability to analyze the equilibrium sorption data at 296 $\mathrm{K}\left(23^{\circ} \mathrm{C}\right)$.

The Langmuir isotherm is probably the best known and most widely applied model of monolayer adsorption of species onto a homogeneous surface with identical adsorption sites. The isotherm can be expressed by the following equation:

$$
Q_{e}=\left(q_{\max } \cdot \mathrm{K}_{L} \cdot \mathrm{C}_{e q}\right) /\left(1+K_{L} \cdot \mathrm{C}_{e q}\right)
$$

...where $Q_{e}$ is the amount of adsorbed americium(III) (mol/g) at equilibrium, $C_{\mathrm{eq}}$ is its equilibrium concentration $\left(\mathrm{mol} / \mathrm{dm}^{3}\right)$ in the solution, and $q_{\max }$ and $K_{L}$ are Langmuir constants related to maximum adsorption capacity (monolayer capacity) (mol/g) and affinity between the sorbent and the sorbate $\left(\mathrm{dm}^{3} / \mathrm{mol}\right)$, respectively. Table 2 shows parameters calculated for the Langmuir model. It can be seen that the values of correlation coefficient $\left(\mathrm{R}^{2}\right)$ are relatively low for all the investigated forms of the adsorbents. The calculated values of $\mathrm{q}_{\max }$ are much higher than the experimental values.

The Langmuir-Freundlich isotherm is expressed by the following equation:

$$
Q_{e}=\frac{a\left(K_{L-F} \times c_{e q}\right)^{n}}{\left[1+\left(K_{L-F} \times c_{e q}\right)^{n}\right]}
$$


...where $Q_{e}$ and $c_{e q}$ denote the equilibrium concentrations of Am in the sorbents and aqueous phases and $a, K_{L-P}$ and $n$ designate the adsorption maximum, adsorption constant, and surface heterogeneity parameter, respectively.

Fig. 3 presents the Langmuir-Freundlich isotherm models fitted to the experimental data. It can be seen that adsorption of $\mathrm{Am}$ ions on $\mathrm{PO}_{4}$-bentonite can be fitted with the linear equation only in the range of the lowest concentrations. The Langmuir-Freundlich model describes adsorption of Am(III) on the examined sorbents very well $\left(\mathrm{R}^{2}=0.99\right.$; Table 2$)$. The values of the $\mathrm{K}_{\mathrm{L}-\mathrm{F}}$ constant are significantly higher for the $\mathrm{PO}_{4}$-sorbent form than for other forms of the sorbent. The values of the power parameter, $\mathrm{n}<1$, indicate heterogeneity and different sorption affinities for different surface areas. The sorption process is best described by the chemisorption mechanism [31-32].

The adsorption capacity reached from the Langmuir-Freundlich model is $0.826 \mathrm{mg} / \mathrm{g}, 9.0882 \mathrm{mg} / \mathrm{g}$, $0.642 \mathrm{mg} / \mathrm{g}$, and $6.707 \mathrm{mg} / \mathrm{g}$ for Na-bentonite, $\mathrm{PO}_{4}$ bentonite, Na-red clay, and $\mathrm{PO}_{4}$-red clay, respectively.

a)
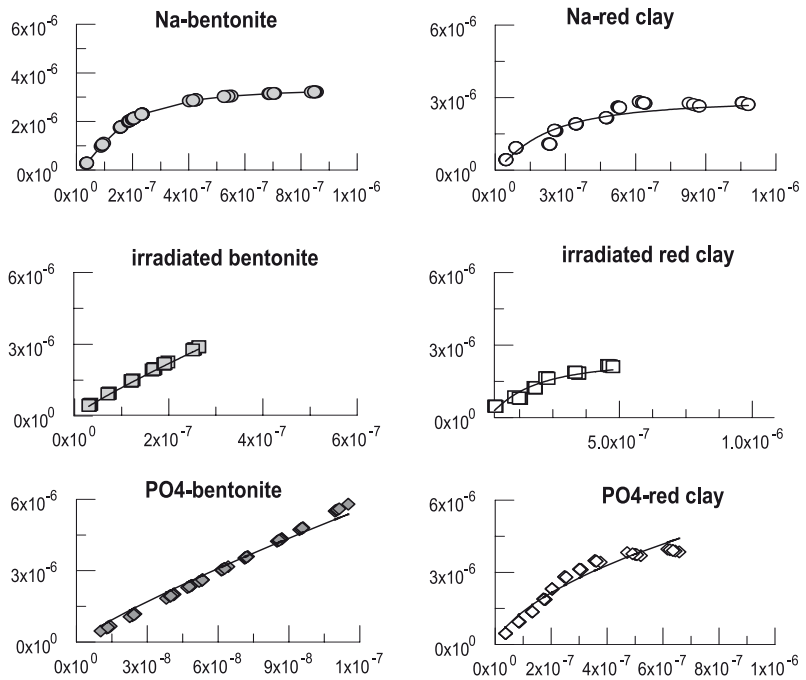

b)

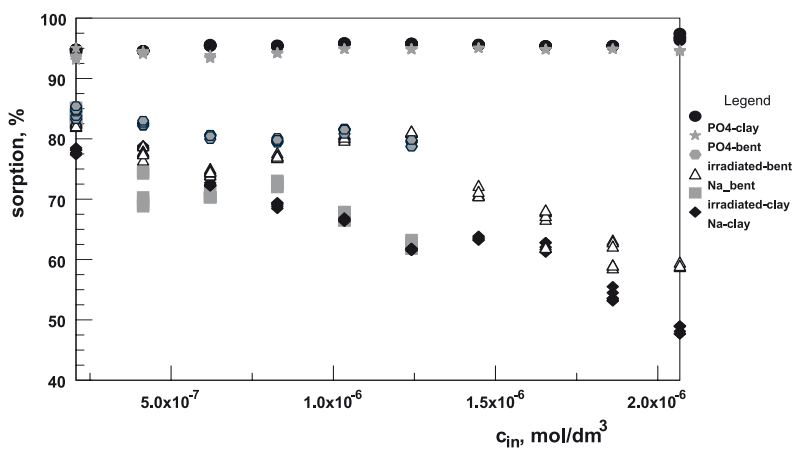

Fig. 3. a) Langmuir-Freundlich isotherms for americium adsorption on Volclay bentonite and red clay (Na-, irradiated, and $\mathrm{PO}_{4}$ forms of adsorbents). b) The effect of initial concentration of americium ions on the adsorption percentage at $23^{\circ} \mathrm{C}$ for $\mathrm{Na}$-, irradiated, and $\mathrm{PO}_{4}$ forms of adsorbents.
According to available literature, the sorption capacities for different sorbents in relation to the Am ions are much lower. The sorption capacities of biomasses of various Rhizopus species is $0.009926 \mathrm{mg} / \mathrm{g}$ [33], $2.64 \mathrm{mg} / \mathrm{g}$ for synthesized macroporous polymeric beads [34], and $8.019 \cdot 10^{-5} \mathrm{mg} / \mathrm{g}$ for alginate gels [35].

The Temkin isotherm, in turn, contains a factor that takes into account the adsorbent-adsorbate interactions. Thus the equation can be used to describe adsorption on heterogeneous surfaces. By ignoring the lowest and the highest concentration values, the model assumes that the heat of adsorption (function of temperature) of all molecules in a layer would decrease linearly rather than logarithmically with increasing surface coverage [36]. The model in its linear form is given as:

$$
Q_{e}=\frac{R T}{b_{T}} \cdot \ln K_{T}+\frac{R T}{b_{T}} \cdot \ln c_{e q}
$$

...where $\mathrm{K}_{\mathrm{T}}$ denotes the equilibrium binding constant $\left(\mathrm{dm}^{3} / \mathrm{g}\right), \mathrm{b}_{\mathrm{T}}$ is the constant related to the heat of adsorption $(\mathrm{J} / \mathrm{mol}), \mathrm{R}$ is the universal gas constant $(8.314 \mathrm{~J} /(\mathrm{mol} \cdot \mathrm{K}))$, and $\mathrm{T}$ is the temperature at $298 \mathrm{~K}$. The values of the constants obtained for the Temkin isotherm are also shown in Table 2. The values of the $b_{\mathrm{T}}$ constant show that the heat of adsorption for $\mathrm{PO}_{4}$-sorbentsis is lower than for $\mathrm{Na}$-sorbents.

The nature of adsorption can also be determined by analyzing equilibrium data using the DubininRadushkevich model (D-R) [37], which is generally applied to express the adsorption mechanism with a Gaussian energy distribution onto a heterogeneous surface. The model has often been shown to fit both high activities of the solute and the intermediate range of concentrations. The adsorption energy is evaluated on the basis of the Dubinin-Radushkevich equation [38]:

$$
c_{S}=Q_{m} \times \exp \left(-K_{D-R} \varepsilon^{2}\right)
$$

...where $\mathrm{c}_{\mathrm{s}}$ is the concentration of Am ions in the solid phase, $Q_{\mathrm{m}}$ is the model constant (mol $\left./ \mathrm{g}\right), K_{\mathrm{D}-\mathrm{R}}$ is the model constant $\left(\mathrm{mol}^{2} / \mathrm{kJ}^{2}\right)$, and $\varepsilon$ relates to the Polanyi term found from the equation:

$$
\varepsilon=R T \ln \left(1+\frac{1}{c_{e q}}\right)
$$

...where $\mathrm{R}$ is a gas constant, $\mathrm{T}$ stands for temperature, and $\mathrm{c}_{\mathrm{s}}$ denotes the concentration of $\mathrm{Am}$ (III) in the equilibrium aqueous phase.

Energy of adsorption, E, can be calculated as:

$$
E=\frac{1}{\left(2 K_{D-R}\right)^{0.5}}
$$

The Dubinin-Radushkevich constant and mean free energy of adsorption are given in Table 2. The value of $\mathrm{E}$ is useful for estimating the type of sorption mechanism 
involved. Adsorption is physical for $\mathrm{E}<8 \mathrm{~kJ} / \mathrm{mol}$, and chemical for $8<\mathrm{E}<16 \mathrm{~kJ} / \mathrm{mol}$ [38]. The values obtained for all forms of Volclay bentonite and red clay are in the range $9-12 \mathrm{~kJ} / \mathrm{mol}$, which means that the process of adsorption of Am ions is chemical in nature.

The $\mathrm{R}^{2}$ values shown in Table 2 demonstrate that the Langmuir-Freundlich and Dubinin-Radushkevich adsorption models fit the experimental data best and can thus be used to predict the adsorption of americium(III) on Volclay bentonite and red clay. This means that the surfaces of these sorbents have a specific number of unevenly distributed sites with different affinities where the molecules can be adsorbed [29].

In order to demonstrate the positive effect of modification of the investigated adsorbents with $\mathrm{PO}_{4}$ ions we represented the percentage of Am sorption as a function of the initial concentration of Am in solutions. Fig. 3b shows a high sorption of $\mathrm{Am}(\mathrm{III})$ (96\%) on $\mathrm{PO}_{4}$-adsorbents, which practically remains constant with the increasing concentration of Am. This fact may indicate that precipitation of Am phosphate is accompanied by the sorption of $\mathrm{Am}$ on $\mathrm{PO}_{4}$-adsorbents. In the case of $\mathrm{Na}$-adsorbents and irradiated adsorbents, adsorption decreases slightly with increasing concentrations of Am in the initial solutions. This shows that, probably, adsorption sites on the surface of the adsorbents have been partly filled.

\section{Effect of Acidity of Solution on Sorption}

Bentonite clay has a very strong negative ionic charge. It attracts species of the opposite, positive charge - not only heavy and/or radioactive metals, but also toxins, harmful bacteria, dyes, and various pathogens [19, 39]. Thus, due to the protonation and deprotonation properties of the sorbent surface, acidity of the solution is an important factor that must be considered in sorption studies. The effect of $\mathrm{pH}$ on $\mathrm{Am}(\mathrm{III})$ removal was studied in the $\mathrm{pH}$ range from 2.0 to 10.0 for the same quantity of adsorbent (about $3.5 \mathrm{~g} \mathrm{~L}^{-1}$ ). The increases in Am(III) sorption with $\mathrm{pH}$ for Na-bentonite and Na-red clay are shown in Fig. $4 \mathrm{a}$. The dotted line refers to the model equation:

$$
\begin{aligned}
& \log K_{d}=\log \left(10^{k A m(3+)} \cdot \alpha_{A m(3+)}+10^{k A m C O 3(+)} \cdot \alpha_{A m C O 3}{ }^{(+)}\right. \\
& +10^{\mathrm{kAm}(\mathrm{CO} 3) 2(-)} \cdot \alpha_{\mathrm{Am}(\mathrm{CO}) 2}{ }^{(-)}+10^{\mathrm{kAm}(\mathrm{CO}) 3(3-)}
\end{aligned}
$$

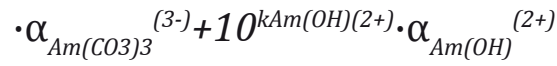

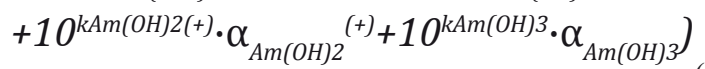

... where the symbols $\alpha_{\mathrm{Am}(\mathrm{III})}, \alpha_{\mathrm{AmCO} 3}{ }^{+}, \ldots$. , etc. denote the molar fractions of $A m(I I I)$ species while the numbers $10^{\mathrm{kAm}(3+)}, 10^{\mathrm{kAmCO} 3+}, \ldots$, etc. refer to the sorptive parameters of these species, i.e., their influence on the value of the distribution constant $\mathrm{K}_{\mathrm{d}}$ of $\mathrm{Am}(\mathrm{III})$ between the aqueous and solid (sorbent) phases. This way of evaluating changes in sorption with $\mathrm{pH}$ was presented in one of our earlier works concerning the sorption of U(VI) ions on bentonite

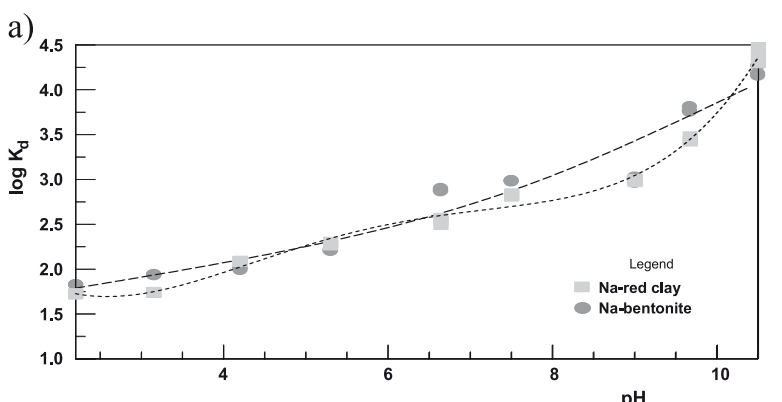

b)

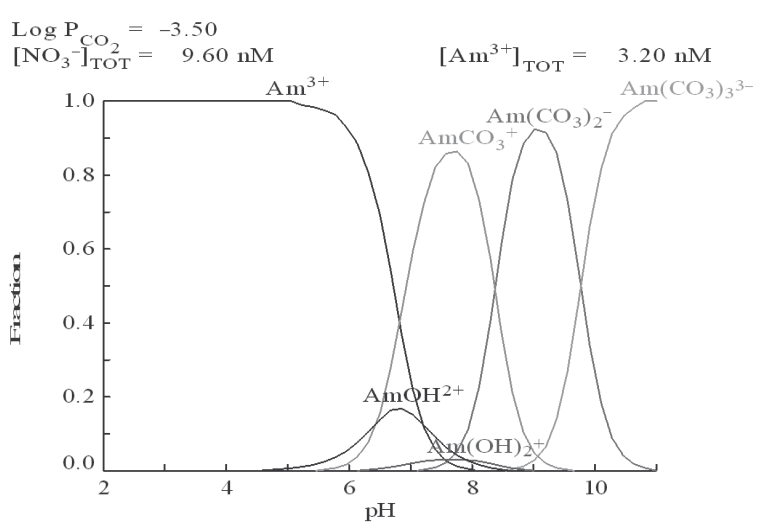

c)

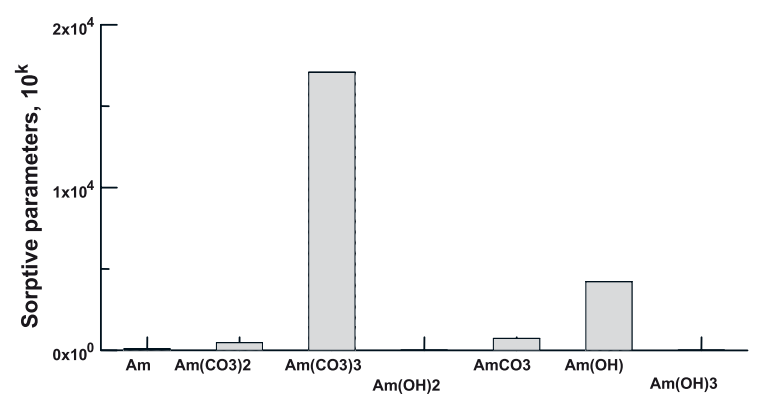

Fig. 4. a) Changes in americium sorption $(\log \mathrm{Kd})$ on Na-bentonite and Na-red clay with an increase in $\mathrm{pH}\left(\mathrm{c}_{\mathrm{in}}=2.07 \times 10^{-8} \mathrm{~mol} /\right.$ $\mathrm{dm}^{3}$ ). b) The change of Am(III) complexes molar fractions with $\mathrm{pH}$ (solid phase excluded from calculations). c) The values of sorptive parameters for molar fractions of particular species with $\mathrm{pH}$.

[18]. In that paper, we clearly showed that the molar fraction of individual complexes in the aqueous phase plays a decisive role in $\mathrm{U}(\mathrm{VI})$ sorption. The values of sorption parameters calculated in this study are given in Figs. 4b$4 \mathrm{c}$, along with the continuous changes in the molar fractions of the particular species with $\mathrm{pH}$. One can notice that the species $\mathrm{Am}^{3+}, \mathrm{Am}(\mathrm{OH})^{2+}, \mathrm{Am}(\mathrm{OH})_{2}^{+}, \mathrm{Am}\left(\mathrm{CO}_{3}\right)^{+}$, and $\mathrm{Am}\left(\mathrm{CO}_{3}\right)_{2}^{-}$have an insignificant effect on Am(III) sorption, i.e., the $\mathrm{k}$ values are small in their case. The main role in $\mathrm{Am}(\mathrm{III})$ transfer from the aqueous to the sorbent phase is played by $\mathrm{Am}\left(\mathrm{CO}_{3}\right)_{3}{ }^{3-}$ and $\mathrm{Am}(\mathrm{OH})_{3}$ species, which are probably responsible for the precipitation of a kind of solid Am(III) carbonate complex on the surface of the sorbent. Unfortunately, it was impossible to include the phosphate complexes of Am in the calculations, since their concentrations in the equilibrium aqueous phase were very low. Nevertheless, there is no doubt that some kind of an Am phosphate complex was formed in the 


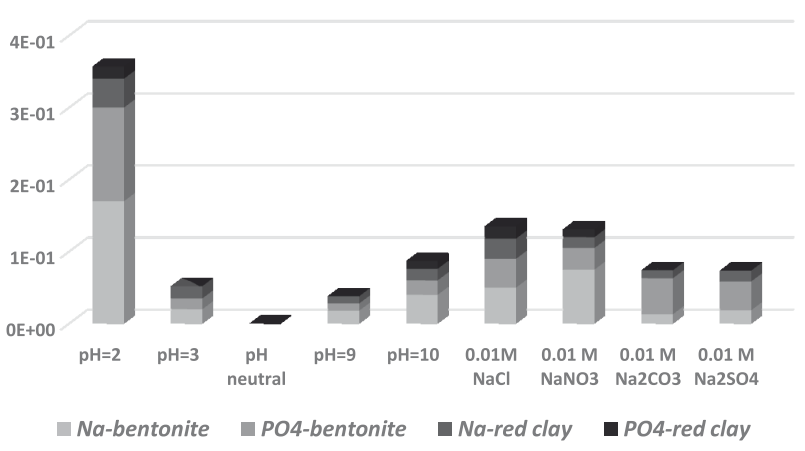

Fig. 5. Desorption of Am(III) from Volclay bentonite and red clay by different aqueous solutions.

sorbent phase as a result of interactions of $\mathrm{Am}\left(\mathrm{CO}_{3}\right)_{3}{ }_{3}^{3-}$ and $\mathrm{Am}(\mathrm{OH})_{3}$ species with the phosphate ions sorbed on the surface of HDTMA+sorbent.

\section{Desorption of Am(III) from Volclay Bentonite and Red Clay}

An attempt to revitalize Am(III)-loaded sorbents was made by shaking the material at room temperature with different types of desorbing agents, namely $0.01 \mathrm{M}$ $\mathrm{NaCl}, 0.01 \mathrm{M} \mathrm{NaNO}_{3}, 0.01 \mathrm{Na}_{2} \mathrm{CO}_{3}$, and $0.01 \mathrm{M} \mathrm{Na}_{2} \mathrm{SO}_{4}$, in drinking water collected at the Institute of Nuclear Chemistry and Technology. Samples of drinking water of different acidities were also tested. The results presented in Fig. 5 show that the percentage of Am(III) in the solution after desorption with each agent did not exceed 1.6\%. Experiments with drinking water at $\mathrm{pH}$ in the range of 2 to 10 also showed strong binding of Am(III) by sorbents. No more than $0.4 \%$ of the adsorbed radioactivity was removed from the material. The good sorptive properties of Volclay bentonite and red clay from Pałęga, combined with their strong affinity for water, make them potentially suitable for protecting barriers in radioactive waste tanks in waste repositories.

\section{Post-decontamination Solutions}

To examine whether bentonite could be used as a sorbent in pretreatment and storage of LLW solutions, granular Volclay bentonite was tested for sorption of Am(III) from artificial post-decontamination liquids. The sorption properties of the sodium form of bentonite were compared with those of the gamma-irradiated material.

It was found that the formation of complexes of Am(III) with strong chelates, such as citrates, did not significantly decrease the sorption efficiency of either form of the sorbent. The percentages of sorption from acidic citrate solutions with $\mathrm{pH}$ values between 2.0 and 3.2 were similar for the two types of bentonite, with a value of about $96.5 \%$. To compare, the percentage of sorption from the contaminated drinking water of similar acidity was only about $92.0 \%$.

\section{Conclusions}

1. Two novel sorbents, $\mathrm{PO}_{4}$-bentonite and $\mathrm{PO}_{4}$-red clay, exhibit very good sorption properties toward Am(III), which surpass those of Na-sorbents. Both of them are potentially good constituents of geological barriers for the immobilization of Am(III) ions.

2. The sorptive properties of the $\mathrm{PO}_{4}$ adsorbents are independent of the initial concentration of Am(III) ions in solution. This proves that apart from chemisorption, sorption on these adsorbents involves precipitation of Am phosphates. It seems that the PO4-bentonite and PO4-red clay case refers to the different mechanism of Am(III) ion sorption. The most probable is the constant exchange of Am(III) ions between equilibrium aqueous phase and the sorbent surface saturated with alkylammonium cations -(HDTMA $)_{2}^{+}$, forming the bilayer that is able to attract phosphate ions with the formation of ionic pairs -(HDTMA) $)_{2}\left(1 / 3 \mathrm{PO}_{4}\right)$. Am(III) ions can therefore be complexed by phosphate ions immobilized on the mineral surface. The precipitation of $\mathrm{AmPO}_{4}$ is possible, but this process cannot dominate the overall sorption of Am(III), since the lack of evident sorption increase is observed with the equilibrium concentration of Am(III).

3. Sorption of Am(III) on Volclay bentonite and red clay from Pałega shows that these materials can be applied for the pretreatment and storage of LLW and MLW solutions in radioactive waste repositories (LLW is low-level waste; MLW is medium-level waste). The desorption experiment supports this conclusion.

4. The observed radiation effects appearing during gamma irradiation of the examined materials do not influence their sorption properties.

5. The Langmuir-Freundlich and Dubinin-Radushkevich models of isotherm adsorption describe the experimental data most accurately. The value of the parameter $\mathrm{n}<1$ indicates that the surface of these sorbents is heterogeneous and exhibits variable affinity. The energy of adsorption calculated for all forms of Volclay and red clay tested is in the energy range of chemisorption, i.e., $8-16 \mathrm{~kJ} / \mathrm{mol}$.

6. Kinetic evaluation of the equilibrium data shows that adsorption of americium ions on Volclay bentonite and red clay closely follows the pseudo-second-order kinetic model.

7. Modeling of Am sorption based on the molar fractions of the particular complexes in the aqueous phase is feasible, i.e., it is possible to predict adsorption based on the molar fractions of the individual americium complexes as a function of $\mathrm{pH}$.

\section{Acknowledgements}

The authors thank Dr. T. Szreder for irradiating the bentonite samples, Dr. J. Dudek for carrying out the ICP- 
MS analyses of the bentonite, and Mr. K. Kulisa (all, INCT) for analyzing the samples of water. We are also indebted to Dr. Wojciech Starosta (INCT) for performing the X-ray studies.

This work was carried out as a part of the strategic project Technologies Supporting Development of Safe Nuclear Power Engineering, Task 4: Development of spent nuclear fuel and radioactive waste management techniques and technologies, supported by the National Centre for Research and Development, Poland (SP/J/4/143 321/11).

\section{References}

1. Report IAEA-TECDOC-1336, Combined methods for liquid radioactive waste treatment. Final report of a coordinated research project 1997-2001, 250, 2003.

2. Report IAEA-TECDOC-675, Use of inorganic sorbents for treatment of liquid radioactive waste and backfill of underground repositories, 183, 1992.

3. ALLARD B., MOULIN V., BASSO L., TRAN M.T., STAMMOSE D. Americium adsorption on alumina in the presence of humic materials, Geoderma 44 (2-3), 181, 1989.

4. SUBBARAO M., GAIKWADA M., RAO V.K., NATARAJAN P.R. Studies on the Adsorption of Americium on Alumina from Aqueous Nitric Acid-Oxalic Acid Solutions, Separ. Sci. Technol. 20 (2-3), 181, 1985.

5. OZAKI T., KIMURA T., OHNUKI T., KIRISHIMA A., YOSHIDA T., ISOBE H., FRANCIS A.J. Association of europium(III), americium(III), and curium(III) with cellulose, chitin, and chitosan. Environ. Toxicol. Chem. 25 (8), 2051, 2006.

6. ALLIOT C., BION L., MERCIER F., VITORAGE P., TOULHOAT P. Effect of aqueous acetic, oxalic and carbonic acids on the adsorption of americium onto $\alpha$-alumina, Radiochim. Acta, 93,435, 2005.

7. SINGHAL R.K., BASU H., MANISHA V., REDDY A.V.R., MUKHERJEE T. Removal of low level americium-241 from potable water originated from different geochemical environments by calcium alginate.Desalination 280, 313, 2011.

8. ZHANG W., HE X., YE G., YI R., CHEN J. Americium(III) capture using phosphonic acid-functionalized silicas with different mesoporous morphologies: adsorption behavior study and mechanism investigation by EXAFS/XPS, Environ. Sci. Technol. 48, 6874, 2014.

9. ALLEN P.G., BUCHER J.J., SHUH D.K., EDELSTEIN N.M., CRAIG I. Coordination Chemistry of Trivalent Lanthanide and Actinide Ions in Dilute and Concentrated Chloride Solutions. Inorg. Chem. 39 (3), 595, 2000.

10. FENG X. G., HE Q.G., WANG J.C., CHEN J. Simultaneous determination of $152 \mathrm{Eu}$ and $241 \mathrm{Am}$ in liquid solution by liquid scintillation counting. J. Radioanal. Nucl. Chem. 295 (2), 1495, 2013.

11. YANG Q., YANG J., LIU J., LI Y., LI C. Synthesis and Characterization of Phosphonic Acid Functionalized Organosilicas with Bimodal Nanostructure. Chem. Mater. 17 (11), 3019, 2005.

12. JOHNSON B., SANTSCHI P., CHUANG C., OTOSAKA S., ADDLEMAN R., DOUGLAS M., RUTLEDGE R., CHOUYYOK W., DAVIDSON J., FRYXELL G., SCHWANTES J. Collection of Lanthanides and Actinides from Natural Waters with Conventional and Nanoporous
Sorbents. Environ. Sci. Technol. 46 (20), 11251, 2012.

13. Smoke detectors and americium-241 fact sheet, www.cnssnc.ca/ecc/cnsecc.html.

14. Americium/Beryllium, www.hightechsource.co.uk/Legacy/ Resources/Americium-Beryllium. PDF

15. WOLD S. Report SKB-TR-10-20: Sorption of prioritized elements on montmorillonite colloids and their potential to transport radionuclides, 40, 2010.

16. GRABIAS E., GŁADYSZ-PŁASKA A., KSIĄŻEK A., MAJDAN M. Phosphate-assisted sorption of U(VI) ions on a red clay, Environ. Chem. Lett. 12 (2), 297, 2014.

17. SINGH A, ULRICH K.U., GIAMMAR D.E. Impact of phosphate on U(VI) immobilization in the presence of goethite, Geochim. Cosmochim. Ac. 74, 6324, 2010.

18. MAJDAN M., PIKUS S., GAJOWIAK A., STERNIK D., ZIEBA E. Uranium sorption on bentonite modified by octadecyltrimethylammonium bromide, J. Hazard. Mater. 184, 662, 2010.

19. PERNYESZI T., KASTEEL R., WITTHUHN B., KLAHRE P., VEREECKEN H., KLUMP E. Organoclays for soil remediation: Adsorption of 2,4-dichlorophenol on organoclay/aquifer material mixtures studied under static and flow conditions, Appl. Clay. Sci. 32, 179, 2006.

20. WANG X., LIU F., TAN W., LI W., FENG X., SPARKS D.L. Characteristics of Phosphate Adsorption-Desorption Onto Ferrihydrite: Comparison With Well-Crystalline Fe (Hydr) Oxides. Soil Sci. 178, 1, 2013.

21. http://www.naturalnews.com/036972_bentonite_clay_ heavy_metals_detox.html

22. WHO Guidelines for drinking-water quality, third edition, incorporating first and second addenda, Volume 1, World Health Organization (WHO), Geneva 2008, ISBN 978-924-154761-1; http://www.who.int/water_sanitation_health/ dwq/ gdwq3rev/en/, 2008.

23. SAG Y., AKTAY Y. Mass transfer and equilibrium studies for the sorption of chromium ions onto chitin. Process Biochem. 36, 157, 2000.

24. BELHACHEMI M., ADDOUN F. Adsorption of congo red onto activated carbons having different surface properties: studies of kinetics and adsorption equilibrium, Desalin. Water. Treat., 37, 122, 2012.

25. ÖZBAY İ., ÖZDEMIR U., ÖZBAY B., VELI S. Kinetic, thermodynamic, and equilibrium studies for adsorption of azo reactive dye onto a novel waste adsorbent: charcoal ash. Desalin. Water. Treat. 51, 6091, 2013.

26. NAIYA T.K., BHATTACHARYA A.K., MANDAL S., DAS S.K. The sorption of lead(II) ions on rice husk ash. J. Hazard. Mater. 163, 1254, 2009.

27. HO Y.S., MCKAY G. Pseudo-second order model for sorption processes. Process Biochem. 34, 451, 1999.

28. ABD EL-LATIF M.M., ELKADY M.F. Equilibrium isotherms for harmful ions sorption using nano zirconium vanadate ion exchanger. Desalination 255, 21, 2010.

29. FOO K.Y., HAMEED B.H. Insights into the modeling of adsorption isotherm systems, Chem. Eng. J. 156, 2, 2010.

30. PIVARCIOVA L., ROSSKOPFOVA M., GALAMBOS P., RAJEC P. Sorption of nickel on chitosan, J. Radioanal. Nucl. Chem. 300 (1), 361, 2014.

31. HO Y.S., PORTER J.F., MCKAY G. Equilibrium isotherm studies for the sorption of divalent metal ions onto peat: copper, nickel and lead single component systems, Water Air Soil Poll. 141, 1, 2002.

32. GUNAY A., ARSLANKAYA E., TOSUN I. Lead removal from aqueous solution by natural and pretreated clinoptilolite: adsorption equilibrium and kinetics, J. Hazard. Mater. 146, 362, 2007. 
33. DHAMI P.S, KANNAN R, NAIK P.W., GOPALAKRISHNAN V., RAMANUJAM A., SALVI N.A., CHATTOPADHYAY S. Biosorption of americium using biomasses of various Rhizopus species, Biotechnol. Lett. 24, 885, 2002.

34. PATHAK S.K., TRIPATHI S.C., SINGH K.K., MAHTELE A.K., KUMAR M., GANDHI P.M. Simultaneous separation and purification of plutonium and americium from aqueous nitrate solutions using extractant impregnated macroporous polymeric beads, J. Radioanal. Nucl. Chem. 308, 47, 2016.

35. SINGHAL R.K., BASU H., MANISHA V., REDDY A.V.R., MUKHERJEE T. Removal of low level americium-241 from potable water originated from different geochemical environments by calcium alginate, Desalination 280, 313, 2011.

36. SUN X., HUANG X., LIAO X., SHI B. Adsorptive recovery of $\mathrm{UO}_{2}{ }^{2+}$ from aqueous solutions using collagen-tannin resin, J. Hazard. Mater. 179, 295, 2010.
37. YUSAN S., AKYILERENTURK S. Adsorption equilibrium and kinetics of U(VI) on beta type of akaganeite, Desalination 263, 233, 2010.

38. VIJAYARAGHAVAN K., PADMESH T.V.N., PALANIVELU K., VELAM M. Biosorption of nickel(II) ions onto Sargassumwightii. Application of two-parameter and threeparameter isotherm models, J. Hazard. Mater. 133 (1-3), 304, 2006.

39. NORRIS S., BRUNO J., CATHELINEAU M., DELAGE P., FAIRHURST C., GAUCHER E.C., HOHN E.H., KALINICHEV A., LALIEUX P., SELLIN P. Clays in Natural and Engineered Barriers for Radioactive Waste Confinement. Geological Society Special Publication 400. London, 2014. 